\title{
Worldwide initiatives aimed to train professionals in the use of the ICD-11
}

\author{
Giulia M. Giordano*
}

\begin{abstract}
Background: The chapter on mental disorders of the 11th revision of the International Classification of Diseases (ICD11) has been now finalized. Training of mental health professionals in the use of the chapter is taking place worldwide.

Main body of the abstract: Information is provided on the ICD-11 training courses taking place recently, including that co-organized by the Naples World Health Organization (WHO) Collaborating Centre on Research and Training in Mental Health and the European Psychiatric Association; those which will be held in the next few months, such as the one co-organized by the World Psychiatric Association and the Global Mental Health Academy, to be held online from 8 to 29 November 2021; and the training course set up by the WHO Collaborating Centre on Mental Health at the Columbia University, in collaboration with the WHO Department of Mental Health and Substance Use, which can be accessed only by the members of the WHO Global Clinical Practice Network.
\end{abstract}

Conclusion: Psychiatrists of all countries of the world are encouraged to become familiar with the ICD-11 chapter on mental disorders, which will be adopted shortly by most countries worldwide.

Keywords: International Classification of Diseases, 11th edition (ICD-11), Chapter on mental disorders, Training of professionals

\section{Background}

The chapter on mental, behavioural and neurodevelopmental disorders of the 11th revision of the International Classification of Diseases (ICD-11), has now been completed. The structure of the chapter, the most important changes with respect to the 10th revision of the International Classification of Diseases, and the most significant differences from the Diagnostic and Statistical Manual of Mental Disorders, 5th edition, have been recently described in detail [1]. The many issues that have been addressed during the development of the chapterincluding the role of a dimensional component, the question of the frequent concomitance of multiple psychiatric diagnoses, and the need of a further characterization of the individual patient after a diagnosis has been made in

*Correspondence: giuliamgiordano@gmail.com

WHO Collaborating Centre for Research and Training in Mental Health,

University of Campania L. Vanvitelli, Naples, Italy order to guide the formulation of the management planhave been discussed in the literature [2-17].

Education and training of mental health professionals in the use of the ICD-11 chapter is now taking place worldwide, mostly focusing on psychiatrists and psychologists, under the supervision of a WHO International Advisory Group led by G.M. Reed. Training courses have been implemented within the 18th and 19th World Congresses of Psychiatry (Mexico City, 2018; Lisbon, 2019) [18-20].

\section{Main text}

In this manuscript, information is provided on the ICD-11 training courses taking place recently. In April 2021, the Naples World Health Organization (WHO) Collaborating Centre on Research and Training in Mental Health and the European Psychiatric Association organized an online 20-h training course, coordinated by G.M. Reed and M. Maj. The course, original author(s) and the source, provide a link to the Creative Commons licence, and indicate if changes were made. The images or other third party material in this article are included in the article's Creative Commons licence, unless indicated otherwise in a credit line to the material. If material is not included in the article's Creative Commons licence and your intended use is not permitted by statutory regulation or exceeds the permitted use, you will need to obtain permission directly from the copyright holder. To view a copy of this licence, visit http://creativecommons.org/licenses/by/4.0/. The Creative Commons Public Domain Dedication waiver (http://creativeco mmons.org/publicdomain/zero/1.0/) applies to the data made available in this article, unless otherwise stated in a credit line to the data. 
subdivided into four sessions, has covered schizophrenia and other primary psychotic disorders, disorders specifically associated with stress, mood disorders, anxiety and fear-related disorders, obsessive-compulsive and related disorders, feeding and eating disorders, personality disorders, disorders due to substance use, disorders due to addictive behaviours, and compulsive sexual behaviour disorder. W. Gaebel, M. Cloitre, M. Maj, C.S. Kogan, P. Monteleone, M. Swales, J.B. Saunders and N.A. Fineberg composed the Faculty.

A similar training course, co-organized by the World Psychiatric Association and the Global Mental Health Academy, will take place online from 8 to 29 November 2021 (see www.wpanet.org). The Faculty will include W. Gaebel, M. Cloitre, M. Maj, C.S. Kogan, O. Gureje, M. Swales, J.B. Saunders and N.A. Fineberg. A training session covering psychotic disorders and mood disorders was organized by the psychiatric association of Turkey in June 2021. A similar event was organized by the UK Royal College of Psychiatrists in May 2021.

The WHO Collaborating Centre on Mental Health at the Columbia University, in collaboration with the WHO Department of Mental Health and Substance Use, has recently set up a training course with exclusive access to the members of the WHO Global Clinical Practice Network (https://gcp.network). The course consists of 15 online training units, each focusing on a different group of disorders and taking from one hour to one hour and a half. Each unit provides a description of the relevant diagnostic group and the main innovations with respect to the ICD-10. The outcome of training is checked through knowledge questions. Participants have the opportunity to practice by applying diagnostic guidelines to clinical case examples. This training course is going to be available also in Spanish, and additional translations are planned.

The WHO Global Clinical Practice Network now includes more than 16,000 clinicians from 159 countries (40\% from Europe, 25\% from Western Pacific, 24\% from the Americas, 5\% from Southeast Asia, 3\% from Eastern Mediterranean, and 3\% from Africa; 63\% from highincome countries, $37 \%$ from middle- and low-income countries). Among them, about $51 \%$ are psychiatrists and $30 \%$ psychologists.

\section{Conclusions}

All health professionals working in mental health or primary care are welcome to join the Network in order to become familiar with the ICD-11 chapter on mental disorders, which will be adopted shortly by most countries worldwide.
Abbreviations

ICD-11: The 11th revision of the International Classification of Diseases; WHO World Health Organization.

\section{Acknowledgements}

Not applicable.

\section{Authors' contributions}

GMG wrote the paper and she is the sole author. The author read and approved the final manuscript.

\section{Funding}

Not applicable.

Availability of data and materials

Data sharing is not applicable to this article as no datasets were generated or analysed during the current study.

\section{Declarations}

Ethics approval and consent to participate

Not applicable.

\section{Consent for publication}

Not applicable.

\section{Competing interests}

The author declares that she has no competing interests.

Received: 29 August 2021 Accepted: 4 September 2021

Published online: 02 November 2021

\section{References}

1. Reed GM, First MB, Kogan CS, Hyman SE, Gureje O, Gaebel W, et al. Innovations and changes in the ICD-11 classification of mental, behavioural and neurodevelopmental disorders. World Psychiatry. 2019;18:3-19. https://doi.org/10.1002/wps.20611.

2. Bryant RA. Post-traumatic stress disorder: a state-of-the-art review of evidence and challenges. World Psychiatry. 2019;18:259-69. https://doi. org/10.1002/wps.20656.

3. Clark LA, Cuthbert B, Lewis-Fernández R, Narrow WE, Reed GM. Three approaches to understanding and classifying mental disorder: ICD-11, DSM-5, and the National Institute of Mental Health's Research Domain Criteria (RDoC). Psychol Sci Public Interest. 2017;18:72-145. https://doi. org/10.1177/1529100617727266.

4. Evans SC, Roberts MC, Keeley JW, Rebello TJ, de la Peña F, Lochman JE, et al. Diagnostic classification of irritability and oppositionality in youth: a global field study comparing ICD-11 with ICD-10 and DSM-5. J Child Psychol Psychiatry. 2021;62:303-12. https://doi.org/10.1111/jcpp.13244.

5. Forbes MK, Wright AGC, Markon KE, Krueger RF. The network approach to psychopathology: promise versus reality. World Psychiatry. 2019;18:272-3. https://doi.org/10.1002/wps.20659.

6. Fusar-Poli P. TRANSD recommendations: improving transdiagnostic research in psychiatry. World Psychiatry. 2019;18:361-2. https://doi.org/ 10.1002/wps.20681.

7. Gaebel W, Reed GM, Jakob R. Neurocognitive disorders in ICD-11: a new proposal and its outcome. World Psychiatry. 2019;18:232-3. https://doi. org/10.1002/wps.20634

8. Gureje O, Lewis-Fernandez R, Hall BJ, Reed GM. Systematic inclusion of culture-related information in ICD-11. World Psychiatry. 2019;18:357-8. https://doi.org/10.1002/wps.20676.

9. Kotov R, Jonas KG, Carpenter WT, Dretsch MN, Eaton NR, Forbes MK, et al. Validity and utility of hierarchical taxonomy of psychopathology (HiTOP): I. Psychosis superspectrum. World Psychiatry. 2020;19:151-72. https://doi. org/10.1002/wps.20730.

10. Maj M, Stein DJ, Parker G, Zimmerman M, Fava GA, De Hert M, et al. The clinical characterization of the adult patient with depression aimed 
at personalization of management. World Psychiatry. 2020;19:269-93. https://doi.org/10.1002/wps.20771.

11. Mansell W. Transdiagnostic psychiatry goes above and beyond classification. World Psychiatry. 2019;18:360-1. https://doi.org/10.1002/wps.20680.

12. Patel $V$. Reimagining outcomes requires reimagining mental health conditions. World Psychiatry. 2019;18:286-7. https://doi.org/10.1002/wps. 20662.

13. Pettersson E, Larsson H, D'Onofrio BM, Bölte S, Lichtenstein P. The general factor of psychopathology: a comparison with the general factor of intelligence with respect to magnitude and predictive validity. World Psychiatry. 2020;19:206-13. https://doi.org/10.1002/wps.20763.

14. Rebello TJ, Keeley JW, Kogan CS, Sharan P, Matsumoto C, Kuligyna M, et al. Anxiety and fear-related disorders in the ICD-11: results from a global case-controlled field study. Arch Med Res. 2019;50:490-501. https://doi. org/10.1016/j.arcmed.2019.12.012.

15. Sanislow CA. RDoC at 10: changing the discourse for psychopathology. World Psychiatry. 2020;19:311-2. https://doi.org/10.1002/wps.20800.

16. van Os J, Guloksuz S, Vijn TW, Hafkenscheid A, Delespaul P. The evidencebased group-level symptom-reduction model as the organizing principle for mental health care: time for change? World Psychiatry. 2019;18:88-96. https://doi.org/10.1002/wps.20609.

17. Widiger TA, Crego $C$. The Five Factor Model of personality structure: an update. World Psychiatry. 2019;18:271-2. https://doi.org/10.1002/wps. 20658.

18. Giallonardo V. ICD-11 sessions within the 18th World Congress of Psychiatry. World Psychiatry. 2019;18:115-6. https://doi.org/10.1002/wps.20612.

19. Perris F. ICD-11 sessions at the 19th World Congress of Psychiatry. World Psychiatry. 2020;19:263-4. https://doi.org/10.1002/wps.20754.

20. Pocai B. The ICD-11 has been adopted by the World Health Assembly. World Psychiatry. 2019;18:371-2. https://doi.org/10.1002/wps.20689.

\section{Publisher's Note}

Springer Nature remains neutral with regard to jurisdictional claims in published maps and institutional affiliations.
Ready to submit your research? Choose BMC and benefit from:

- fast, convenient online submission

- thorough peer review by experienced researchers in your field

- rapid publication on acceptance

- support for research data, including large and complex data types

- gold Open Access which fosters wider collaboration and increased citations

- maximum visibility for your research: over $100 \mathrm{M}$ website views per year

At BMC, research is always in progress.

Learn more biomedcentral.com/submissions 